\title{
"United territorial communities in Ukraine in the context of fiscal decentralization"
}

\begin{tabular}{|c|c|}
\hline \multirow{10}{*}{ AUTHORS } & Alina Korbutiak iD https://orcid.org/0000-0002-9330-7145 \\
\hline & R http://www.researcherid.com/rid/S-4327-2016 \\
\hline & Zhanna Lysenko iD https://orcid.org/0000-0002-1882-9672 \\
\hline & R http://www.researcherid.com/rid/S-4722-2016 \\
\hline & Nataliya Sokrovolska iD https://orcid.org/0000-0001-8778-7317 \\
\hline & $\mathbb{R}$ http://www.researcherid.com/rid/R-8418-2016 \\
\hline & Artur Oleksyn (D) http://orcid.org/0000-0002-4194-5962 \\
\hline & R http://www.researcherid.com/rid/S-1805-2016 \\
\hline & Eduard Yurii iD http://orcid.org/0000-0001-9987-4629 \\
\hline & R http://www.researcherid.com/rid/R-9472-2016 \\
\hline ARTICLE INFO & $\begin{array}{l}\text { Alina Korbutiak, Zhanna Lysenko, Nataliya Sokrovolska, Artur Oleksyn and } \\
\text { Eduard Yurii (2019). United territorial communities in Ukraine in the context of } \\
\text { fiscal decentralization. Problems and Perspectives in Management, 17(2), 217- } \\
\text { 227. doi:10.21511/ppm.17(2).2019.16 }\end{array}$ \\
\hline DOI & http://dx.doi.org/10.21511/ppm.17(2).2019.16 \\
\hline RELEASED ON & Tuesday, 21 May 2019 \\
\hline RECEIVED ON & Monday, 03 December 2018 \\
\hline \multirow[t]{2}{*}{ ACCEPTED ON } & Friday, 26 April 2019 \\
\hline & $(c)) \overline{E Y}$ \\
\hline LICENSE & $\begin{array}{l}\text { This work is licensed under a Creative Commons Attribution } 4.0 \text { International } \\
\text { License }\end{array}$ \\
\hline JOURNAL & "Problems and Perspectives in Management" \\
\hline ISSN PRINT & $1727-7051$ \\
\hline ISSN ONLINE & $1810-5467$ \\
\hline PUBLISHER & LLC "Consulting Publishing Company "Business Perspectives" \\
\hline FOUNDER & LLC "Consulting Publishing Company "Business Perspectives" \\
\hline
\end{tabular}

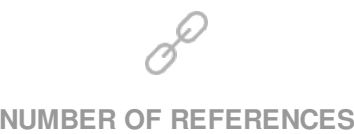

35

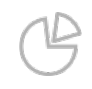

NUMBER OF FIGURES

1

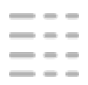

NUMBER OF TABLES

4

(C) The author(s) 2023. This publication is an open access article. 


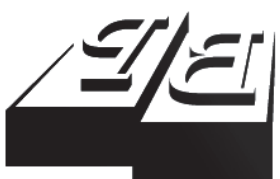

BUSINESS PERSPECTIVES

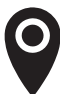

LLC "CPC "Business Perspectives"

Hryhorii Skovoroda lane, 10,

Sumy, 40022, Ukraine

www.businessperspectives.org

Received on: $3^{\text {rd }}$ of December, 2018 Accepted on: $26^{\text {th }}$ of April, 2019

(C) Alina Korbutiak, Zhanna Lysenko, Nataliya Sokrovolska, Artur Oleksyn, Eduard Yurii, 2019

Alina Korbutiak, Ph.D. in Economics, Assistant Lecturer, Department of Public, Corporate Finance and Financial Intermediation, Yuriy Fedkovych Chernivtsi National University, Ukraine.

Zhanna Lysenko, Ph.D. in Economics, Associate Professor, Department of Public, Corporate Finance and Financial Intermediation, Yuriy Fedkovych Chernivtsi National University, Ukraine.

Nataliya Sokrovolska, Ph.D in Economics, Associate Professor, Department of Public, Corporate Finance and Financial Intermediation, Yuriy Fedkovych Chernivtsi National University, Ukraine.

Artur Oleksyn, Ph.D. in Economics, Associate Professor, Department of Public, Corporate Finance and Financial Intermediation, Yuriy Fedkovych Chernivtsi National University, Ukraine.

Eduard Yurii, Ph.D. in Economics, Head of the Department of Public, Corporate Finance and Financial Intermediation, Yuriy Fedkovych Chernivtsi National University, Ukraine.

\section{(ㄷ)(i)}

This is an Open Access article, distributed under the terms of the Creative Commons Attribution 4.0 International license, which permits unrestricted re-use, distribution, and reproduction in any medium, provided the original work is properly cited.

Alina Korbutiak (Ukraine), Zhanna Lysenko (Ukraine), Nataliya Sokrovolska

(Ukraine), Artur Oleksyn (Ukraine), Eduard Yurii (Ukraine)

\title{
UNITED TERRITORIAL COMMUNITIES IN UKRAINE IN THE CONTEXT OF FISCAL DECENTRALIZATION
}

\begin{abstract}
Since the beginning of the administrative and territorial reform in Ukraine, the financial decentralization process has been intensified. It aims at optimizing the budgetary resource redistribution in order to make communities financially independent. This significantly increases the financial capacity for self-organization and self-development of a united territorial community, which determines the need to apply valuation methods to increase the territory's investment attractiveness.
\end{abstract}

The article outlines the peculiarities of the united territorial communities (UTCs) management under fiscal decentralization, taking into account the need to apply current methods of value-oriented management. At the same time, the use of SWOT analysis as one of the methods of value-oriented management made it possible to evaluate the efficiency and attractiveness of UTCs under decentralization. The financial activity of 665 UTCs was analyzed and the model for managing the united territorial community was created. It is emphasized that the modern understanding of financial support for united territorial communities remains unresolved today, and the expediency to introduce changes in the UTC, which envisage using the subsidiarity principles, is not justified.

The key directions for managing the UTCs are identified. This refers to communities that began their activities and already faced the first challenges: management of available resources, provision of needs and sustainable development of the community, changes in the ratio of their income and expenditure components, increase in the budget income per capita.

It is recommended to focus on tools of value-oriented management in the united territorial communities in order to attract investors and increase the financial capacity of local authorities.

\section{Keywords}

\section{JEL Classification}

\section{INTRODUCTION}

During the current period of Ukraine's statehood, fiscal decentralization becomes a topical issue, since it is one of the fundamental conditions for the effective functioning of local authorities. Excessive centralization of the executive authorities' powers and the corresponding financial and material resources for their implementation, which took place in Ukraine until 2015, led to the need for decentralization reforms with the provision of significant powers to the territorial communities, giving them greater resources for local development. The separation of the territorial community as the basic local self-government entity, ensuring its establishment as a self-sufficient, efficient and effective link management are the key aspects in this process. 
The urgency of the subject is due primarily to the fact that financial decentralization is one of the most acute problems of the general decentralization, the solution of which will enable both to accelerate its implementation and to ensure the proper socio-economic development of territorial communities.

Nowadays, in Ukraine, there is no full and self-sufficient regional self-government at district and region territorial levels. There are no tools to support this self-sufficiency, including regional ownership, regional spending powers and regional taxes. Therefore, one of the results of fiscal decentralization is expected to reduce corruption risks and ensure free access to information in the spatial and resource conditions for doing business in the united territorial communities as a result of changes in the administrative and territorial structure of Ukraine. Changing the administrative and territorial structure in Ukraine expands opportunities for attracting investment and increasing the territory's capacity.

At the initial stage of the reform, financial preferences are not a determining factor in the community creation. Administrative decisions, including administrative pressure, resistance to reform by district and local government officials, activity of rural residents, etc. play a key role. According to Danylyshyn and Pylypiv (2016), a similar situation has taken place in many European countries, since fiscal decentralization only creates opportunities for more responsible and effective management system, the use of territorial communities' resources. However, the findings do not refute the assertion that fiscal decentralization is a significant lever for accelerating reform in general, because united territorial communities have substantially increased their revenues, which can be used to address many socio-economic problems.

Due to a number of measures, in particular amendments to the Budget Code and the Tax Code of Ukraine, during the period 2015-2017, the general fund and the own revenues of the united territorial communities increased significantly. Different tax revenues make the basis for the UTCs' own revenues. However, the key role belongs to the personal income tax, which accounts for about $50 \%$ of communities' own revenue. Despite the help of the state, most of the newly formed territorial communities remain subsidized. Only about $20 \%$ of the territorial communities are financially autonomous.

\section{LITERATURE REVIEW}

Both Ukrainian and foreign scientists investigate the development of territorial communities as socio-economic development management entities. At the same time, in the Ukrainian scientific literature, there are underinvestigated issues related to the formation of the financial and economic capacity of territorial communities under systemic transformations in economics and public administration, taking into account the provisions and objectives of the reform of local self-government, including the creation of viable territorial communities, the use of financial analysis tools (method of coefficients, vertical analysis, etc.) to assess the investment capacity of the community.

In economic terms, Weingast (1997), Rodden (2002), Rodden and Rose-Ackerman (1997) take a favorable view of the fiscal decentralization processes. The authors note that decentralization gives more opportunities for local governments to attract investors, creating favorable conditions for the migration of production factors. In this case, Rodden and Rose-Akerman (1997) warn that the magnitude of the positive effects of fiscal decentralization processes depends on the development of the institutional environment, including providing conditions for competition.

Italian scholars Bartolini, Sacchi, Salotti, and Santolini (2018) substantiated the positive impact of fiscal decentralization not only on the finances of local authorities, but also on public finances in general. They proved that tax autonomy will improve the budget of all levels of power, which suggests that more "effective" tax decentralization will increase budgetary discipline during financial crisis.

Bisogno, Cuadrado-Ballesteros, Santis, and Citro (2018) also investigated the indicators of financial 
autonomy of local authorities, which provide reliable information to local politicians and authorities for making managerial decisions. In particular, it has been determined that sustainability, flexibility and vulnerability are positively related to financial autonomy and current equilibrium and are negatively related to the debt position and investment level.

According to Japanese scholars Akai and Sakata (2002), fiscal decentralization contributes to economic growth, since it allows for more objective assessment of the impact of its implementation on the local level.

Turkish researchers Eroğlu and Serbes (2018) substantiated the system of financial autonomy indicators, which will affect the fiscal decentralization efficiency. It is proved that local authorities, which are closest to citizens, should be financially strong in order to be able to provide efficient and high-quality services. It is substantiated that the municipalities in Turkey have enough own income and autonomy in the planning and budget process, therefore, the quality of their services increases and they can more effectively manage their resources.

Ukrainian scholars Kyrylenko, Malyniak, Pysmennyi, and Rusin (2015) also proved that the financial resources of the capable territorial communities are the most important criterion that can ensure sustainable economic development of the community, region and the state in general (according to the Cabinet of Ministers of Ukraine (2016) data). It is essential to have a common understanding of the phrase "territorial community". The territorial community is a naturally formed human community, whose members are individuals who live, work or possess real estate in one or more settlements with a single administrative center and are characterized by a combination of stable linkages and are able to realize common interests in their own livelihoods and socio-economic development. This community acts as a representative of the local community and has communal property in the respective territory. Butko (1992) notes that the territorial community is people who live within certain territorial boundaries and have common interests. Kravchenko (1999) defines a territorial community as a group of cit- izens living together in an urban or rural settlement, having collective interests and the legal status determined by law. According to Baimuratov (2001), the territorial community is a set of individuals who reside permanently in a certain territory and are connected by territorial and personal systemic linkages.

An important component of the current functioning of the territories in terms of fiscal decentralization is the real and objective assessment of their investment attractiveness and capacity, based on the application of specific methods and tools, including VBM technologies. The abbreviation VBM (value-based management) appeared in Ukraine in the early 1990s when Koller, Goedhart, and Wessels (1990) wrote their work "Valuation: Measuring and Managing the Value of Companies". This work became the basis of managing the values in the world, particularly in Ukraine. The concept of companies' cost management as a new ideology of corporate governance was born in the 1980s. Rappaport (1986) was the first to substantiate value-based management in the United States. In his work "Creating shareholder value: the new standard for business performance", he proved first the need to focus managers' efforts on increasing value for investors. The main idea, according to Rappaport (1986), is to assess the effectiveness of the investment and financial strategy of the corporation based on its ability to create the value of shares (added value of shareholders). In his another work "Ten Ways to Create Shareholder Value", Rappaport (2006) first identified the basic principles of VBM at the enterprise.

American scholars Chapman (2015), Young and O'Byrne (2014), Ittner and Larcker (2016) analyze the main components of strategic management in general and value-oriented one in particular. The authors determined that management systems are often seen as inappropriate or even harmful strategies. The specific ways in which control systems can build and maintain valuable strategic roles are given. The general methodological and econometric problems are substantiated, ways of future research in the field of strategic management in general and economically-oriented management are proposed. Ameels, Bruggeman, and Scheipers (2002) define the role of value management in in- 
creasing the value of companies. Hoetker (2007) notes the possibility of using logical and probit models while studying strategic management. Munima (2008) proposes implementing a value management system in non-governmental organizations. In addition, Firk, Schmidt, and Wolff (2017) analyzed potential economic benefits and institutional impacts in the management of values.

Since then, the VBM concept in Ukraine is only related to the corporate sector, and this study involves a methodology for assessing the investment attractiveness of an administrative unit (UTC) as a business entity, and not as a legal entity.

Contemporary territorial communities should utilize the proposed cost-based management models that are used to improve the calculation of sustainable value added by incorporating sustainability indicators for environmental, social and corporate governance. Dočekalová and Kocmanová (2018) offer models that include 11 ecological, social and corporate indicators of sustainable development and economic indicators (interest income, taxes, depreciation and added value), weighting coefficients and target orientation. Ukrainian scientists Kraidych and Haharin (2016) scrutinized problems of cost-effective management of the enterprise development. They offered the concept of managing the values of an enterprise, its characteristics and scale.

The main aspects of the essence of the enterprise resource management system are reflected in the scientific works of many scientists, experts in economics and finance of the leading EU countries, the USA and Japan. So, Fernandez, Zainol, and Ahmad (2017) analyzed the impact of the ERP (Enterprise Resources Planning) system on local authorities using two balanced indicators: financial and consumer ones. The study provides evidence based on a survey conducted by 52 local authorities in Malaysia that have implemented the ERP system. Empirical evidence suggests that the use of ERP systems in local authorities has led to positive financial indicators and improved customer service. Olson, Johansson, and Atem (2015), Young and O'Byrne (2014), Karim, Somers, and Bhattacherjee (2007) justified the feasibility of the use of free ERP or open source ERP to manage economic entities.
At the same time, taking into account Ukrainian realities and world experience, there are no effective tools for assessing the investment attractiveness of a particular united territorial community; there is no information system for collecting, processing and protecting information in community life and its financial support, and there are difficulties with the use of developed foreign methods in Ukraine.

\section{RESEARCH PURPOSE}

The purpose of the study is to determine the peculiarities of management in the united territorial communities under fiscal decentralization, taking into account the necessity of applying value-oriented management methods.

\section{RESEARCH METHODS}

While managing the united territorial community in the context of fiscal decentralization, it is proposed to use methodological approaches that cover both known methods of financial analysis (method of coefficients, vertical analysis, etc.), and specific instruments of financial control (EVA method, SWOT analysis, etc.).

\section{RESULTS}

The implementation of the process of consolidating territorial communities in Ukraine began in the middle of 2015, when 159 UTCs were created. They united 795 local councils. On October 25,2015 , new municipalities were selected in these communities, and from January 1, 2016, they switched to direct budgetary calculations with the state budget of Ukraine. According to the 2016 results, there was positive dynamics in their development. Thus, in 2016, there was a significant progress in the UTC creation - their number increased by 2.3 times (additional 207 UTCs were created). Thus, as of the beginning of 2017, there were 366 UTCs in Ukraine that united 1,740 local councils.

According to the results of the monitoring of the Ministry of Regional Development (2017), as of 


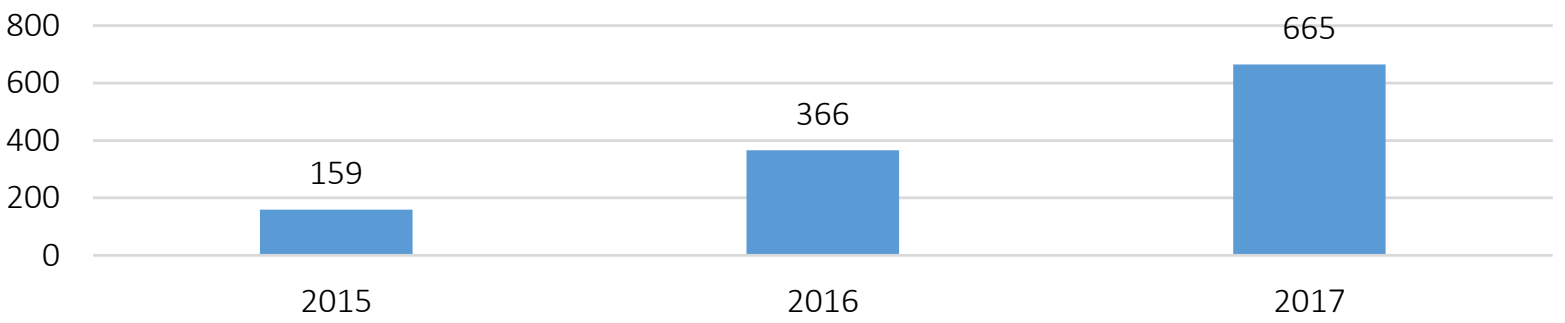

Figure 1. Dynamics of the UTC number in Ukraine in 2015-2017

January 1, 2018, 699 UTCs were created in Ukraine, 3,264 local councils $(29.1 \%$ of the total number of base councils as of January 1,2015) were united, in which 6 million inhabitants live $(14.3 \%$ of the total population of Ukraine). Figure 1 clearly confirms the positive dynamics of the number of UTCs in Ukraine (in 2015-2017, their number increased by 4.2 times (from 159 UTCs in 2015 to 665 in 2017)).

Decentralization of budgetary financial resources implies a change of transfer policy that cannot be built on the Soviet principle "from each according to his ability to each according to his need"; giving local government bodies greater powers towards development and implementation of various socio-economic development programs; change in the tax system, which changes the specific revenues in favor of local budgets (see Table 1).

Table 1. The tax base of the UTC budgets before and after decentralization

\begin{tabular}{l|c|c}
\hline Financial resources & $\begin{array}{c}\text { Before the } \\
\text { reform, \% }\end{array}$ & $\begin{array}{c}\text { After the } \\
\text { reform, \% }\end{array}$ \\
\hline Personal income tax & 25 & 60 \\
\hline Self-employment tax & 0 & 10 \\
\hline Excise tax & 0 & 100 \\
\hline Educational subvention & 0 & $\begin{array}{c}\text { According } \\
\text { to the formula }\end{array}$ \\
\hline Medical subvention & 0 & $\begin{array}{c}\text { According } \\
\text { to the formula }\end{array}$ \\
\hline Real property tax & 1 & $0-3$ \\
\hline
\end{tabular}

In 2015, the legal framework was laid down for encouraging territorial communities to unite and switch to direct inter-budget relations with resource provision and powers, as for cities of regional significance. In addition, the state financially supported the united territorial communities and provided a subvention in the state budget for creating their territory infrastructure.

The main goal of reforming local self-government in Ukraine is to boost economic growth based on the bottom-up principle through the effective use of UTC's own socio-economic resources. Thus, in 2017, UAH 502.1 billion came, which was $37.2 \%$, or UAH 136.1 billion, more than in 2016. Local budget, excluding inter-budget transfers, received UAH $229.5 \mathrm{bln}$, which was UAH $58.9 \mathrm{bln}$, or $34.5 \%$, more than in 2016 (see Table 2).

As can be seen from the Table 2 data, local budget revenues grow rapidly. However, local budget revenues, excluding inter-budget transfers, grow at a slower pace $(34.5 \%$ in 2016$)$ than total local budget revenues $(37.2 \%$ in 2016$)$. This indicates an increase in the revenue base of local budgets through transfers coming from the state budget. This is due to a change in the rules for equalization of the local budget capacity and the receipt of targeted transfers for the financing of state-guaranteed services.

Table 2. Dynamics of income constituents of local budgets in 2015-2017

\begin{tabular}{|c|c|c|c|c|c|}
\hline Income & $\begin{array}{l}\text { Actual income } \\
\text { for 2015, UAH } \\
\text { bln }\end{array}$ & $\begin{array}{c}\text { Actual } \\
\text { income for } \\
\text { 2016, UAH } \\
\text { bln }\end{array}$ & $\begin{array}{c}\text { Growth rate, } \\
2016 \text { to } 2015, \\
\%\end{array}$ & $\begin{array}{l}\text { Actual income } \\
\text { for 2017, UAH } \\
\text { bln }\end{array}$ & $\begin{array}{c}\text { Growth rate, } \\
2017 \text { to 2016, } \\
\%\end{array}$ \\
\hline $\begin{array}{l}\text { Total income of local budgets, taking into } \\
\text { account inter-budget transfers }\end{array}$ & 294.5 & 366.0 & 24.3 & 502.1 & 37.2 \\
\hline $\begin{array}{l}\text { Total income of local budgets without } \\
\text { taking into account inter-budget transfers }\end{array}$ & 120.5 & 170.6 & 41.7 & 229.5 & 34.5 \\
\hline Total inter-budget transfers & 173.9 & 195.4 & 12.3 & 272.6 & 39.5 \\
\hline
\end{tabular}


Table 3. Dynamics of the inter-budget transfer structure for 2015-2017

\begin{tabular}{|c|c|c|c|c|c|c|}
\hline Income & $\begin{array}{l}\text { Actual } \\
\text { income } \\
\text { for } 2015 \text {, } \\
\text { UAH bln }\end{array}$ & $\begin{array}{l}\text { Relative } \\
\text { share, \% }\end{array}$ & $\begin{array}{c}\text { Actual } \\
\text { income for } \\
\text { 2016, UAH } \\
\text { bln }\end{array}$ & $\begin{array}{l}\text { Relarive } \\
\text { share, \% }\end{array}$ & $\begin{array}{c}\text { Actual } \\
\text { income for } \\
2017, \\
\text { UAH bln }\end{array}$ & $\begin{array}{l}\text { Relative } \\
\text { share, \% }\end{array}$ \\
\hline Total inter-budget transfers, including: & 173.9 & 100 & 195.4 & 100 & 272.6 & 100 \\
\hline Grants, including: & 7.3 & 4.2 & 6.8 & 3.5 & 22.0 & 8.1 \\
\hline base grant & 5.3 & 3.0 & 4.7 & 2.4 & 5.8 & 2.1 \\
\hline stabilizing grant & 2 & 1.2 & 2 & 1.0 & 1.1 & 0.4 \\
\hline grant to maintain educational and health facilities & 0 & 0.0 & 0 & 0.0 & 14.9 & 5.5 \\
\hline Subventions, including: & 166.6 & 95.8 & 188.6 & 96.5 & 250.6 & 91.9 \\
\hline $\begin{array}{l}\text { subvention for payment of benefit to families with } \\
\text { kids and other benefits }\end{array}$ & 41.9 & 24.1 & 47.2 & 24.2 & 51.6 & 18.9 \\
\hline subvention for subsidies & 19.1 & 11.0 & 46.3 & 23.7 & 72.3 & 26.5 \\
\hline subvention for the employee training & 5.5 & 3.2 & 0 & 0.0 & 0 & 0.0 \\
\hline Educational subvention & 44.1 & 25.4 & 44.5 & 22.8 & 51.5 & 18.9 \\
\hline Health subvention & 46.2 & 26.6 & 44.4 & 22.7 & 56.2 & 20.6 \\
\hline Other subventions & 9.8 & 5.6 & 6.3 & 3.2 & 19.2 & 7.0 \\
\hline
\end{tabular}

In more detail, the structure of inter-budget relations can be seen in Table 3 .

As can be seen, the total amount of inter-budget transfers increases from year to year, and in 2017, it amounts to UAH $272.6 \mathrm{bln}$. In the transfer structure, subventions have the largest relative share, in particular $26.5 \%$ for subsidies, $20.6 \%$ for health and $18.9 \%$ for education. According to the authors, financing expenditures at the expense of the corresponding targeted subventions from the state budget is a progressive step towards reforming budgetary relations, but the very procedure for their calculation, the list of expenditures to be taken into account need to be clarified and supplemented. In particular, when planning subventions in the educational and medical fields, it is critical to take into account all the costs necessary to finance institutions in these areas at the local level without creating additional costs for local budgets.

This, in turn, requires capable territorial communities that can bear responsibility for the economic development of territories and for the formation of a healthy living environment for inhabitants. First of all, it is about changing the mental model for both representatives of local government bodies at the base level and for every citizen of the community - the rejection of paternalistic expectations and understanding of their own responsibility for the community. At the same time, reforming the administrative and territorial system, in particu- lar, in the creation of a UTC based on community consolidation, is accompanied by a number of complex problems, which, on the one hand, inhibits these processes, expanding them in time, and, on the other hand, reduces the socio-economic efficiency of their functioning.

The larger the UTC population, the higher own revenues per one resident of the community. Instead, communities with low population have limited capacity for sustainable development and provision of all necessary services to their residents.

In Ukraine, the community's capacity is determined according to four key criteria: own income per one resident; the level of budget subsidization (the relative share of base/reverse subsidies in income); the relative share of expenditures on maintenance of the management apparatus in UTC own resources (without transfers from the state budget); and capital expenditures per one resident. Based on these indicators, a general UTC rating has been formed.

The analysis of the monitoring carried out by the Ministry of Regional Development, Construction, Housing and Communal Services of Ukraine (2017) shows that the lowest indicators of financial capacity are typical for most of small communities. The exception is some small communities where major budget revenue generating enterprises and powerful enterprises of the real sector of the economy are located. 
Table 4. UTC distribution by population in 2017

\begin{tabular}{l|l|c|c|c}
\hline Groups & $\begin{array}{c}\text { Population size, thousand } \\
\text { people }\end{array}$ & $\begin{array}{c}\text { Number } \\
\text { of UTCs }\end{array}$ & $\begin{array}{c}\text { Total population in the } \\
\text { group, thousand people }\end{array}$ & $\begin{array}{c}\text { \% of total population of the } \\
\text { UTC under study }\end{array}$ \\
\hline Group 1 & Over 15 thousand people & 54 & $1,165.2$ & 37.3 \\
\hline Group 2 & 10 to 15 thousand people & 45 & 549.2 & 17.6 \\
\hline Group 3 & 5 to 10 thousand people & 135 & 940.5 & \\
\hline Group 4 & 5 thousand people and more & 132 & 468.8 & $3,123.7$ \\
\hline Total & & 366 & & 15.0 \\
\hline
\end{tabular}

The regularities between the financial capacity and the population size of the community can be explained by the fact that it is more profitable to develop small and medium businesses in large communities. This is because there is a sufficient labor force, more powerful local market for goods and services, and better prospects for sustainable community development. Large communities have more potential and more opportunities to ensure proper maintenance of infrastructure facilities, functioning of communal property institutions, and local self-government bodies can provide high-quality public and communal services. Thus, in the context of four UTC groups by demographic features, the most numerous are Group 2 and Group 3 (see Table 4).

The given data make it possible to state the rather dynamic formation of united territorial communities in Ukraine, and significant steps were made in 2017 to improve the legislative and normative support for the UTC creation and development. At the same time, there are many unresolved problems, both strategic and operational, that shape the risks for successful further reform.

It should be particularly noted that the creation of much of UTCs occurs without taking into account the requirements of the methodology for their creation. Separate UTCs are formed with the purpose of obtaining additional powers and resources, but according to their potential, they are objectively not able to provide their residents with the appropriate services and to intensify economic processes because of lack of the appropriate infrastructure and resources. They also are not able to ensure sustainable development of communities in the future. Further extension of this practice poses a threat to the leveling of the reform essence, because, instead of capable territorial communities, small communities with underdeveloped infrastructure and insufficient human resources are created.
The consolidation of territorial communities enables local authorities to ensure the proper functioning of the budgetary institutions and independently solve the issues of community development without resorting to the central authorities regarding the allocation of additional funds from the state budget.

Equally relevant in terms of assessing the level of financial support for the development of territorial communities is an analysis of the expenditure structure aimed at the community development. Most of the local budget expenditures are traditionally directed at social and cultural needs (education, health care, social protection, social security, culture and arts, physical culture and sports), which in their content are delegated expenditures, that is those transferred from higher management levels. According to monitoring conducted by the Ministry of Regional Development, Construction and Housing and Communal Services of Ukraine (2017), in the reporting period, the aggregate share of these expenditures in the structure of local budget expenditures accounted for $78.7 \%$. According to the statistics obtained, the highest level of capital expenditures per capita is found in Dnipropetrovsk, Donetsk, Zakarpattia, Mykolaiv, Poltava, Sumy, Kherson and Chernihiv regions. Their indicator amounted to more than UAH 12,661. Capital expenditures below UAH 1,200 per one UTC's resident are recorded in nine regions, including the same Ivano-Frankivsk, Lviv and Chernivtsi regions as well as Kyiv, Kirovohrad, Luhansk, Ternopil, Khmelnytskyi and Cherkasy regions.

Ukrainian literature does not mention the term "value management of a united territorial community". This is due to the fact that the concept of VBM (value-based management) proposed by Chapman (2015), Young and O'Byrne (2014), and Ittner and Larcker (2016) has been applied to the corporate sector. 
This study suggests using value-oriented management tools and assessing the investment attractiveness of a UTC, since the community is considered an independent organization that cares about its own investment attractiveness and is interested in mobilizing financial resources to succeed in a competitive environment. Valuation is carried out with one ultimate goal, namely the implementation of competent management of the relevant entity activity on the basis of forecast data obtained in the evaluation process, so that the entity could fulfill its main economic function - to be profitable.

It should be noted that the main thesis of the VBM concept is that the ability to increase value is impossible to buy and difficult to copy. So united territorial communities should independently formulate such a concept, taking into account a financial control instrument such as SWOT analysis. Since the EVA economic indicator takes into account the profits received, the investor's risk profile and costs incurred, this indicator is quite acceptable for assessing the UTC efficiency. And it is with the help of such tools, according to the authors, that it is advisable to assess the investment attractiveness of the newly formed UTCs.

\section{DISCUSSION}

Overseas studies have shown that companies that use VBM management principles formulated within this concept prevail over companies in similar industries through the use of more efficient business organization system. Therefore, the authors of the study see the benefits of using the VBM management principles in creating an investment attractive UTC, as far as possible today, taking into account all available barriers, including the peculiarities of financial reporting, additional material and human costs, the construction of special calculation models, etc.

According to the findings, it is summarized that the community development costs, as shown by the example of UTCs analyzed, are characterized by direct dependence on the level of UTC budgets autonomy, and in particular on the amount of own income.
Formation of financial and economic capacity of territorial communities in Ukraine takes place in the context of reforming local self-government. Most of the European countries have already undergone a stage of reforming the administrative and territorial structure and creating an effective local self-government. Therefore, the characteristic of the reforming the system of local self-government in the EU countries as a prerequisite for creating financial and economic capacity of territories is a particularly urgent issue for Ukraine so far. The World Bank's first Global Report, "Decentralization and local democracy in the world" (2008), states that the EU countries have two key features that distinguish them from all other geopolitical regions of the world. First, each part of the EU territory is governed by local self-government body. Second, all the EU states recognize the discrete set of fundamental principles based on which local self-government is formed and developed. These principles are reflected and enshrined in the European Charter of Local SelfGovernment, the Convention on the Participation of Foreigners in Public Life at Local Level, the European Outline Convention on Transfrontier Co-operation between Territorial Communities or Authorities, the European Charter for Cities, the European Charter for Regional or Minority Languages, the Framework Convention for the Protection of National Minorities, etc.

Since the middle of the last century, local self-government reforms in the EU countries took place with varying intensity and peculiarities. If the Western European countries have passed this stage for quite a long time, then, in the countries of Central and Eastern Europe this process began much later due to the historical peculiarities of their development and coincided with the election of their European integration development direction (which nowadays is typical for Ukraine). The reform of local self-government in the EU countries included the following areas: change of the administrative and territorial system, organizational reforms, functional and procedural changes, financial reforms. One of the key areas of reform was the reduction in the number of administrative units, in particular at the municipal level. Given the complexity of reform, the definition of the territorial basis of local self-government has become a fundamental condition for effective reforms. 
The creation of so-called special tax districts is the source of attracting financial resources to ensure the economic development of the municipality in the EU countries. Such a mechanism is used mainly by local government bodies in cities. Thus, the municipality creates a special tax district within its territory in which residents are subject to an additional tax, which is used to implement individual projects. Attracted funds are often directed to infrastructure development in support of large private investment project (for example, water supply and sewage systems necessary to support large housing construction). In Ukraine, the State Fund for Regional Development was created. This gave opportunities for minimizing the corruption component when allocating funds from the state budget to the region budgets, and also introduced a competitive selection of regional development projects. An Internet portal under the Ministry of Regional Development has been created. Through it, it is possible to directly register projects submitted for funding from the State Fund for Regional Development (SFRD).
During 2016-2020, Ukraine will have to receive a lot of funds in the form of international technical assistance that is intended to support decentralization and UTCs: EU project ULIED - a total of EUR 97 million; US project DOBRE - the total amount is USD $50 \mathrm{mln}$; Projects of the Council of Europe, the Kingdom of Sweden, the Kingdom of Denmark, the Kingdom of the Netherlands, the Swiss Confederation, Finland, Canada - over EUR 20 million.

Using the SFRD funds, subventions for the UTC infrastructure development should be subject to some approaches that would ensure efficiency, that is funds should be used where it will be most effective; quick wins - the first funds should be used where the results will be immediately visible (light, for example); long-term positive effects - increased capitalization of communal property and land; openness - people should know where and why these funds go; competitiveness - the money is spent based on open tenders (the valid tender saves up to $30 \%$ of money).

\section{CONCLUSION}

Local self-government bodies in the EU possess tools for economic development. Unfortunately, today in Ukraine, the VBM concept is related only to the corporate sector, and this study involves highlighting the methods of assessing the investment attractiveness of the administrative unit itself, as a business, not legal, entity.

There remained a number of problems that need to be solved. First, ensuring the economic development of territorial communities requires creating administrative and territorial units that meet the specific requirements and conditions of the state's development. Second, the authority transfer to a local level should be accompanied by the transfer of appropriate financial resources. Third, effective local self-government, within the limits of the given powers and resources, should function to ensure the economic development of the territory, attracting investment resources and preserving and developing the functioning of the enterprises in the territory.

Consequently, the decision to unite territorial communities should naturally come after the comprehensive assessment of the community status - potential members of the association according to their internal capacity components, based on calculating the aggregate demographic, economic, financial and other indicators, as well as creating a profile of the community's future capacity. This will make it possible to create a community that is really capable of mobilizing internal reserves and independently, at the expense of its own resources, dealing with local issues in terms of the fullest satisfaction of residents' common needs and sustainable community development. The state as a formal institution regulating social relations by issuing acts of law application, which are mandatory for all actors to perform, should play an important role. It is the synergy between the state and the community that provides the opportunity to ensure the real capacity of the territorial communities. 
In this regard, improving the mechanisms of interaction between the state and the community in the area of ensuring the capacity of territorial communities to address local issues should be the perspective for further analysis. According to the authors, the prospects for further research are also in the development of a specific methodology for assessing investment attractiveness using the EVA indicator for a particular UTC. The development of research is related to the study of effective tools for assessing the attractiveness of a particular community, since there are difficulties in using developed foreign methods in Ukrainian environment.

\section{REFERENCES}

1. Akai, N., \& Sakata, M. (2002). Fiscal decentralization contributes to economic growth: Evidence from state-level cross-section data for the United States. Journal of Urban Economics, 52(1), 93-108. https://doi.org/10.1016/S00941190(02)00018-9

2. Ameels, A., Bruggeman, W., \& Scheipers, G. (2002). Valuebased management: an integrated approach to value creation, a literature review (75 p.). Retrieved from http://www.valuebasedmanagement.net/articles_ameels_valuebased_full.pdf

3. Baimuratov, М. О. (2001). Територіальна громада в політичній системі і системі місцевого самоврядування України [Terytorialna hromada v politychnii systemi i systemi mistsevoho samovriaduvannia]. In V. F. Pohorilko \& O. F. Frytskyi (Eds.), Муніципальне право України [Munitsypalne pravo Ukrainy] (pp. 122-123).

4. Bartolini, D., Sacchi, A., Salotti, S., \& Santolini, R. (2018). Fiscal Decentralization in Times of Financial Crises. CESifo Economic Studies, 64(3), 456-488. https://doi. org/10.1093/cesifo/ifx008

5. Baymuratov, M. A. (2004), Публичная самоуправленческая (муниципальная) власть и гражданское общество: проблемы взаимосвязи и взаимозависимости [Publichnaya samoupravlencheskaya (munitsipalnaya) vlast i grazhdanskoye obshchestvo: problemy vzaimosvyazi i vzaimozavisimosti]. Pravo i politika, 3, 82-87.

6. Bisogno, M., Cuadrado-Ballesteros, B., Santis, S., \& Citro, F.
(2018). Budgetary solvency of Italian local governments: an assessment. International Journal of Public Sector Management, 32(2), 122-141. https://doi.org/10.1108/ IJPSM-11-2017-0328

7. Burns, D., Hambleton, R., \& Hoggett, P. (1994). The Politics of Decentralization Revitalising Local Democracy. Basingstoke and London: Macmillan.

8. Butko, I. (1992). Деякі проблеми становлення і розвитку територіального самоврядування в Україні [Deyaki problemy stanovlennya i rozvytku terytorialnoho samovryaduvannya v Ukrayini. Mistseve ta rehionalne samovriaduvannia Ukrainy, 3, 8-15.

9. Cabinet of Ministers of Ukraine (2016). Децентралізачія. Місиеві бюджети 159 об'єднаних територіальних громад [Detsentralizatsiia. Mistsevi biudzhety 159 obiiednanykh terytorialnykh hromad]. Retrieved from https://www.kmu.gov.ua/ storage/app/media/reforms/53-rezultati-finansovogo-monitoringu159-otg-za-2016-rik-stvorenikhu-2015-rotsi.pdf

10. Chapman, C. S. (2015). Controlling Strategy: Management, Accounting, and Performance Measurement. OUP: Oxford.

11. Danylyshyn, B. M., \& Pylypiv, V. V. (2016). Децентралізація у країнах ЄС: уроки для України [Detsentralizatsiia u krainakh YeS: uroky dlia Ukrainy]. Rehionalna ekonomika, 1, 5-11.

12. Dočekalová, M. P., \& Kocmanová, A. (2018). Comparison of Sustainable Environmental, Social, and Corporate Governance Value
Added Models for Investors Decision Making. Sustainability, 10(3), 649. https://doi.org/10.3390/ su10030649

13. Eroğlu, E., \& Serbes, H. (2018). Fiscal autonomy of sub-central in Turkey. In M. P. R. Bolívar \& M. D. L. Subires (Eds.), Financial Sustainability and Intergenerational Equity in Local Governments (pp. 83-100). IGI Global. https:// doi.org/10.4018/978-1-5225-37137.ch004

14. Fernandez, D., Zainol, Z., \& Ahmad, H. (2017). The impacts of ERP systems on public sector organizations. Procedia Computer Science, 111, 31-36. http://dx.doi. org/10.1016/j.procs.2017.06.006

15. Firk, S., Schmidt, T., \& Wolff, M. (2017). Exploring Value-Based Management Sophistication - The Role of Potential Economic Benefits and Institutional Influences. Contemporary Accounting Research, Forthcoming. http://dx.doi. org/10.2139/ssrn.2686447

16. Hoetker, G. (2007). The use of logit and probit models in strategic management research: critical issues. Strategic Management Journal, 28(4). http://dx.doi. org/10.1002/smj.582

17. Ittner, C. D., \& Larcker, D. F. (2016). Assessing empirical research in managerial accounting: a value-based management perspective. Journal of Accounting and Economics, 32(1-3), 349-410. http://dx.doi.org/10.1016/S01654101(01)00026-X

18. Karim, J., Somers, T., \& Bhattacherjee, A. (2007). The impact of ERP implementation on business process outcomes: a factor-based study. Journal of Managing 
Information Systems, 24(1), 101134. http://dx.doi.org/10.2753/ MIS0742-1222240103

19. Koller, T., Goedhart, M., \& Wessels, D. (1990). Valuation: Measuring and Managing the Value of Companies. New Jersey: John Wiley \& Sons, Inc.

20. Kraidych, I. M., \& Haharin, A. О. (2016). Проблеми вартісноорієнтованого управління розвитком підприємства [Problemy vartisno-oriientovanoho upravlinnia rozvytkom pidpryiemstva]. Ekonomichnyi visnyk NTUU "KPI", 13, 208-212. Retrieved from http://ev.fmm.kpi. ua/article/view/80123

21. Kravchenko, V. (1999). Місиеві бінанси України [Mistsevi finansy Ukrainy]. Kyiv: Znannia.

22. Kyrylenko, O., Malyniak, B., Pysmennyi, V., \& Rusin, V. (2015). Планування та управління фінансовими ресурсами територіальної громади [Plaпиvannia ta upravlinnia finansovymy resursamy terytorialnoi hramady]. Kyiv: Pidpryiemstvo "Vienei".

23. Melekhina, I. I. (2003). Местное сообщество: Теоретикоправовой анализ [Mеstnoe soobshchestvo: Teoretiko-pravovoy analiz] (Ph.D. Thesis). Krasnodar.

24. Ministry of Regional Development, Construction, Housing and Communal Services of Ukraine. (2017). Оцінка фінансової спроможності 366 OTГ [Otsinka finansovoi spromozhnosti 366 OTH]. Retrieved from https:// storage.decentralization.gov.ua/ uploads/attachment/document/69 /\%D0\%A0\%D0\%B5\%D0\%B9\%D1 $\% 82 \% \mathrm{D} 0 \% \mathrm{~B} 8 \% \mathrm{D} 0 \% \mathrm{BD} \% \mathrm{D} 0 \% \mathrm{~B} 3$ $366 \% \mathrm{D} 0 \% 9 \mathrm{E} \% \mathrm{D} 0 \% \mathrm{~A} 2 \% \mathrm{D} 0 \% 93$ 9_\%D0\%BCi\%D1\%81.pdf

25. Olson, D., Johansson, B., \& Carvalho, R. A. (2015). Open source ERP business model framework. Robotics and ComputerIntegrated Manufacturing, 50, 30-36. https://doi.org/10.1016/j. rcim.2015.09.007

26. Rappaport, A. (1986). Creating shareholder value: the new standard for business performance. NewYork: FreePress; London: Collier Macmillan.

27. Rappaport, A. (2006). Ten Ways to Create Shareholder Value. Harward Business Review. Retrieved from https://hbr.org/2006/09/tenways-to-create-shareholder-value

28. Rodden, J. (2002). Dilemma Fiscal Federalism: Grants and Fiscal Indicators in the World. American Journal of Political Science, 46(3), 670-687. Retrieved from https:// web.stanford.edu/ jrodden/ AJPS.2002.pdf

29. Rodden, J. S., \& Rose-Ackerman, S. (1997). Is Federalism a Reserve of Markets? Law Review, Virginia, 83(7), 1521-1572. Retrieved from https://www.jstor.org/ stable/1073767

30. Rosacker, K. M., \& Rosacker, R. E. (2010). Information technology project management within public sector organizations. Journal of Enterprise Information Manage- ment, 23(5), 587-594. https://doi. org/10.1108/17410391011083047

31. Siddika, M. (2008). A Proposal to Introduce Value Based Management in NGOs of Bangladesh. Journal of Business and Economics, 3(2), 1-15. Retrieved from https:// papers.ssrn.com/sol3/papers. cfm?abstract $\_\mathrm{id}=1315963$

32. The World Bank. (2008). Decentralization and local democracy in the world: 2008 first global report by united cities and local governments (350 p.). Washington, DC: World Bank. Retrieved from http://documents.worldbank.org/ curated/en/728181468331905029/ Decentralization-and-local-democracy-in-the-world-2008-firstglobal-report-by-united-citiesand-local-governments

33. Weingast, B. R. (1997). The Political Foundations of Democracy and the Rule of Law. The American Political Science Review, 91(2), 245-263. Retrieved from http:// www.jstor.org/stable/2952354

34. Wicksell, K. (1967). A new principle of just taxation. In R. Musgrave \& A. T. Peacock (Eds.), Classics in the Theory of Public Finance (pp. 72-118). New York: St. Martin's Press. Retrieved from http://desmarais-tremblay. com/Resources/Musgrave $\% 20$ Peacock\%201958\%20Classics\%20 in $\% 20$ the $\% 20$ Theory\%20of\%20 Public\%20Finance.pdf

35. Young, S. D., \& O'Byrne, S. F. (2014). EVA and Value-Based Management: A Practical Guide to Implementation (493 p.). McGrawHill. 